
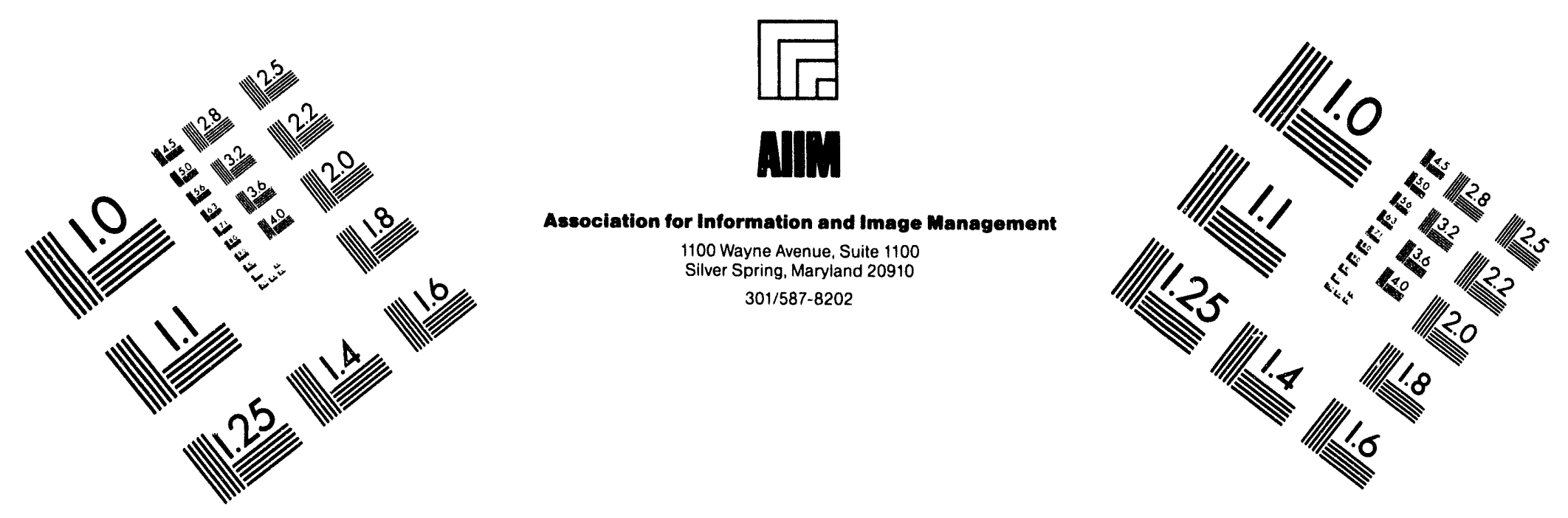

\title{
Centimeter
}

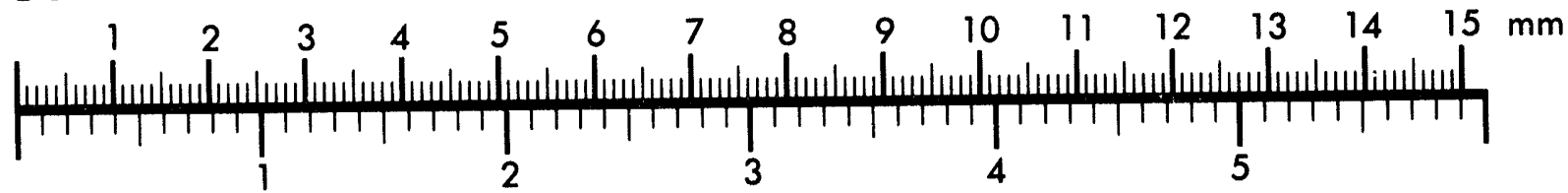

Inches
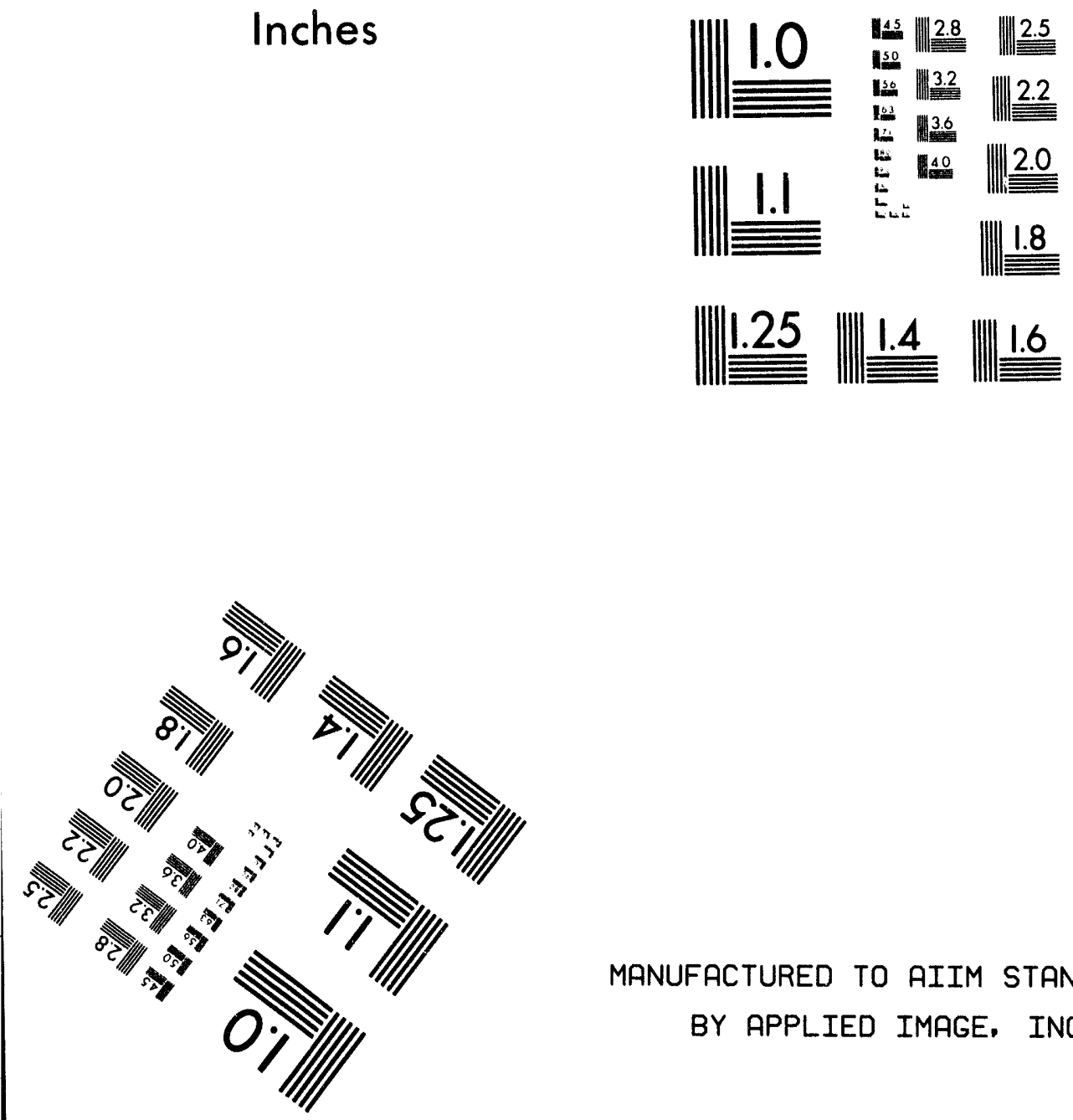

MANUFACTURED TO AIIM STANDARDS

BY APPLIED IMAGE, INC.

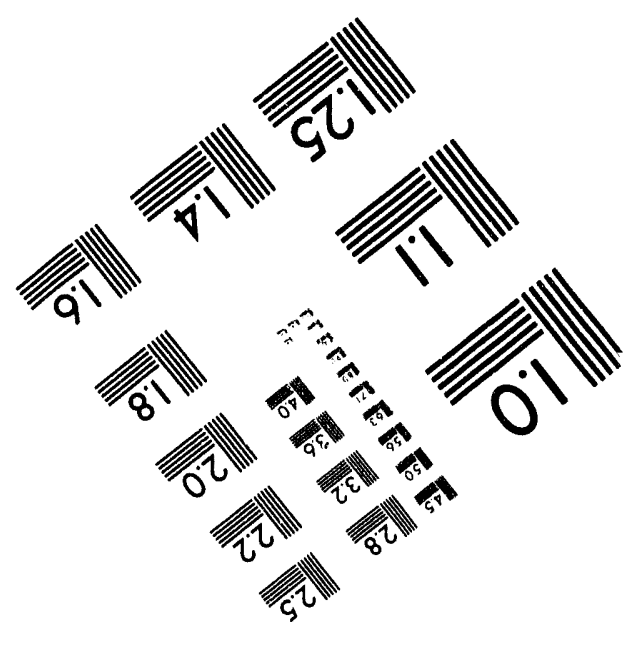



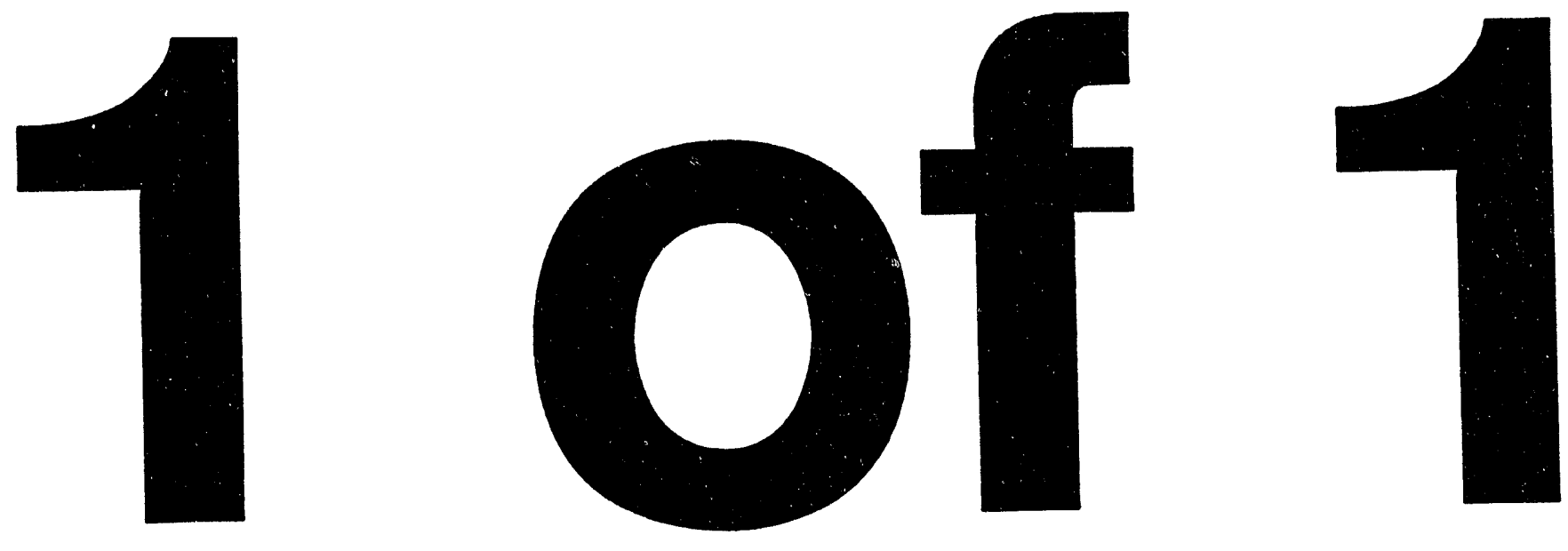


\section{GENERAL (gLCTRIC}

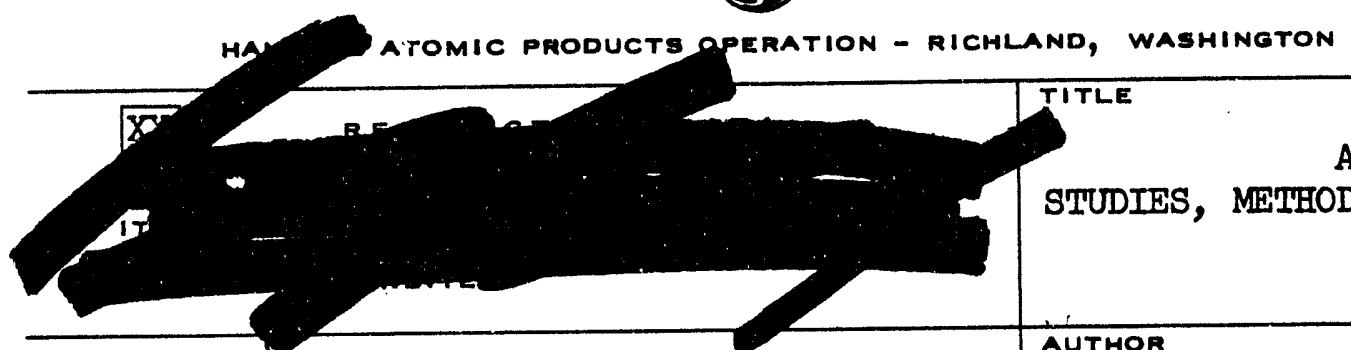

ALSI SLOPOVERS

December 7, 1963

HW-82046

GERIES ANDGORY NO.

AUTHOR

OTHER OFFICIAL CLASSIFIED INFORMATION THIS MATERIAL CONTAINS INFORMATION AFFECTING THE NATIONAL DEFENSE OF THE UNITED STATES WITHIN THE MEANING OF THE ESPIONAGE LAWS, TITLE 18, U. S. C., SECS. T93 AND 794, THE TRANSMISSION OR REVELATION OF WHICH IN ANY MANNER TO AN UNAUTHORIZED PERBON IS PROHIBITED BY LAW.

J. D. Schaffer

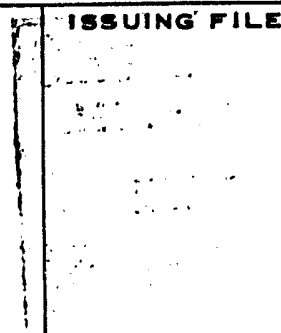

THIS DOCUM TO IT. GUAP

T NOT BE LEFT UNAT

MED OR WHERE AN UNAUTM IN AN APPROVED LO?

PERSON MAY hAVE TORY WITHIN AN NEA. WHILE IT 18 Y UESSION AND UNTIL NE OBTAINEDA SIGNED

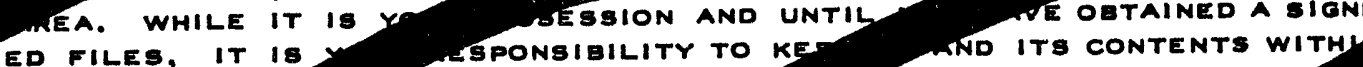
RANSMITTAL TO, AND STP LICATED. IF ADDITIONM S PROJECT AND FROM OP RESIDENCE IS R D. IT IS NOT TO RED. IT IS NOT TO MLICATED. IF AODITIOM OBTAIN THEM FROM RELATED ISSUING FILE. ULLL PERSONS READING TO SIGN IN THE SPACE PROVIDED BELOW.

\begin{tabular}{|c|c|c|c|c|}
\hline ROUTE TO: & PAYROLL NO. & LOCATION & FILES ROUTE & SIGNATURE AND DATE \\
\hline N.C.7n2 & 1209 & 3702 & $5-11-64$ & \\
\hline
\end{tabular}

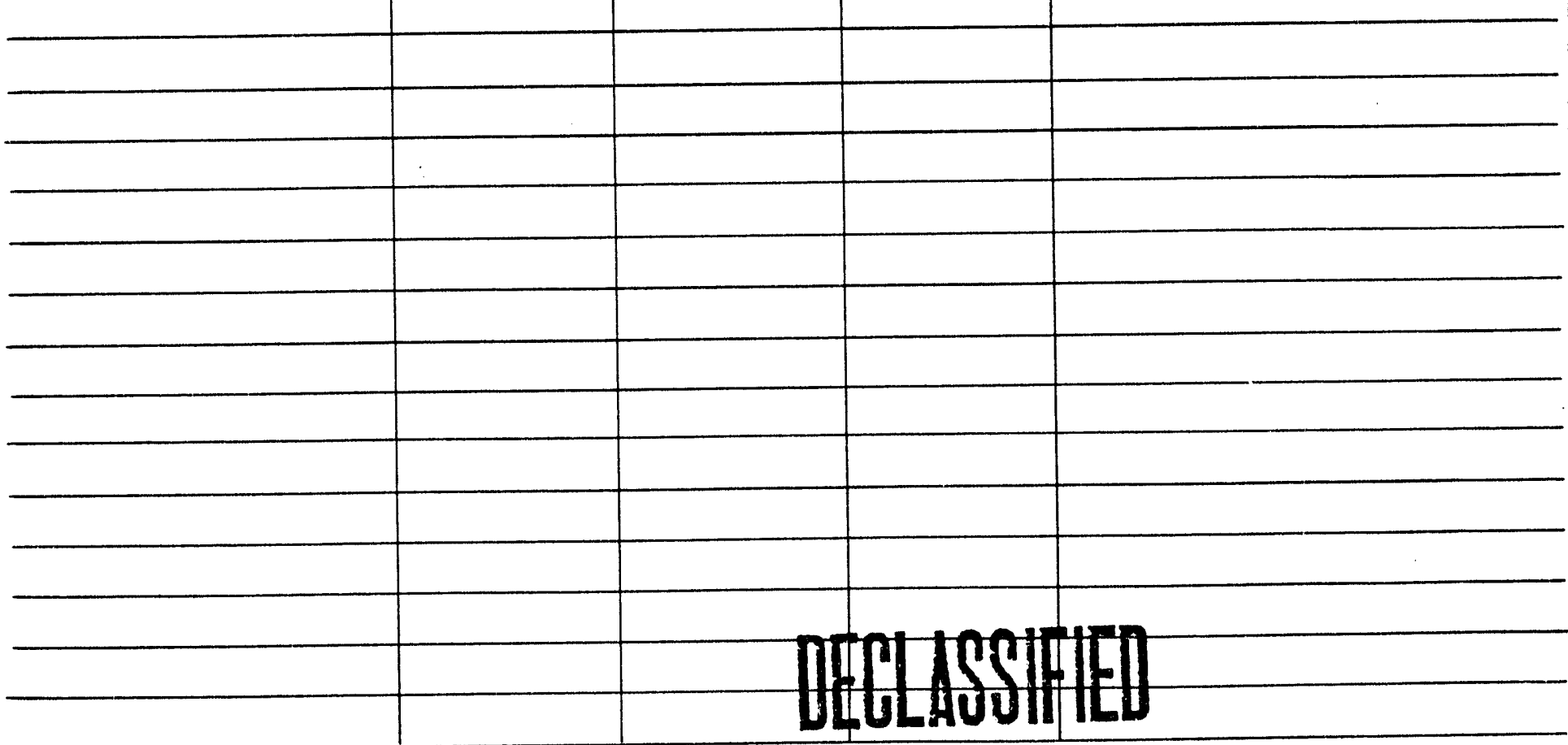


This report was prepared as an account of work sponsored by an agency of the United States Government. Neither the United States Government nor any agency thereof, nor any of their employees, makes any warranty, express or implied, or assumes any legal liability or responsibility for the accuracy, completeness, or usefulness of any information, apparatus, product, or process disclosed, or represents that its use would not infringe privately owned rights. Reference herein to any specific commercial product, process, or service by trade name, trademark, manufacturer, or otherwise does not necessarily constitute or imply its endorsement, recommendation, or favoring by the United States Government or any agency thereof. The views and opinions of authors expressed herein do not necessarily state or reflect those of the United States Government or any agency thereof.

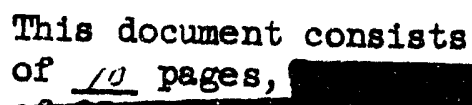

\section{ALSI SLOPOVERS}

\section{STUDIES, METHOD OF ELIMINATION, \& RESULTS}

By

\author{
J. D. Schaffer \\ Process Control Unit \\ Fuels Englneering Subsection \\ Production Fuels Section \\ IRRADIATION PROCESSING DEPARTMENT
}

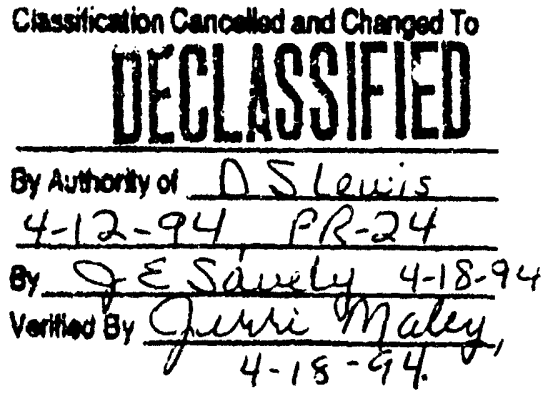

December 7, 1963

Explains steps taken to reduce the CPR rate to a consistently low figure and the theory involved.

\section{Distribution}

1. JG Batchelor

2. RC Bell

3. HE Berg

4. WA Blanton

5. JA Cowan

6. GB Hansen

7. DC Harland

8. CM Heeb

9. KI HLadek

10. WH Hodgson

11. GA Hufe

12. RL Huff

13. F Hunter

14. OB Isaacs

15. FW Knight

16. WC Mayer

17. WM Mertens

18. WN Mobley
19. HC Money

20. RR Muller

21. VH Nelson

22. EV Padgett

23. HG Powers

24. PG Rhoades

25. JD Schaffer

26. CA Strand

27. JT Stringer

28. HF Tew

29. VP Thomes

30. FW Van Wormer

31. FL Van Wyck

32. EA Weakley

33. JJ Wick

34. 300 Files

35. Record Center

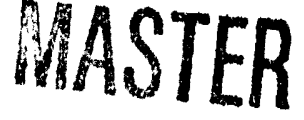

DISTRIBUTION OF THIS DOCUMENT IS UNLIMITED
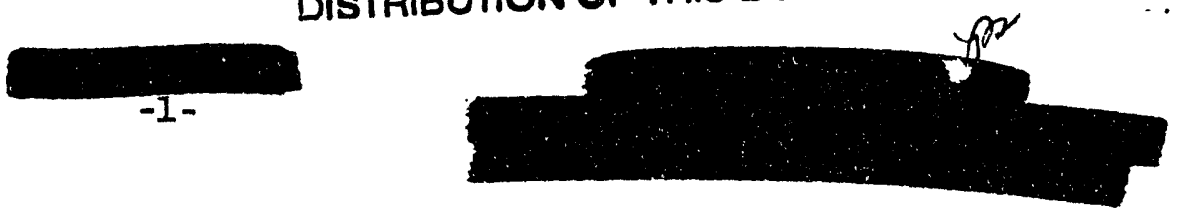
STUDIES, METHOD OF ELIMINATION, \& RESUTTS

\section{INTRODUCTION}

In the process of fuel element assembly, a dip-brazing process, the aluminum can which is ultimately a jacket for a uranium core is protected from the molten Alsi solution by a steel sleeve. Once the can is inserted into the sleeve and thermal expansion is complete, a mechanical block is accomplished by upset metal rings that prevent molten AlSi from flowing between the can and sleeve, a situation that warrants rejection of the assembled element. Passage of the molten solution beyond the upset metal to a point on the can wall not removed during the subsequent facing operation is called an "AlSi Slopover" or "Slop." See flgure I. "A" represents an assembled fuel element rejected as a slopover; " $B$ " is a slopover element after cap-end facing.

\section{SUMMARY}

With discovery of a solution* which would effectively mask $8001-F$ aluminum alloy from molten AlSi, efforts were immediately directed towards using this solution to eliminate AlSi slopovers. With proper application and control, PWR 125 proved that cans coated with PXI288 did not allow AlS1 in the molten state to pass beyond the upset metal region during canning. Since this material has been used on total production, the CPR rate has been greatly reduced. Currently, the percentage of rejects attributable to the CPR category is approximately fire-tenths of one percent $(0.5 \%)$.

\section{THEORY}

Because the use of PXI288 has proven so successful in reducing the number of Alsi slopovers, it is felt that an explanation of the theory and action involved is in order.

PXI288, when properly used, offers two beneficial effects:

1. A physical block is created in view of the thickness of the film deposited around the upset metal of the can. This impedes the flow of Alsi.

2. The presence of $P X 1288$ on the surface of the aluminum can reduces the solid surface tension, thus reducing the wettability of the surface.

When a film presents a sufficiently non-wettable surface, the molten AlSi will not spread; such conditions have been described as "autophobic." Consider a drop of molten AlSi on a smooth horlzontal surface of $8001-F$ alloy. Assuming the aluminum is clean and deoxidized, without PXI288 the drop will spread itself over a relatively large area. The AlSi has wet

\footnotetext{
FPXI288-A DIversey Corporation experimental product consisting mainly of sodium, phosphorus, and silicon (named "Seren-dip" by author).
} 
the aluminum. With PXI288 on the surface, the drop would remain in drop form and no spreading would occur. The latter is the case when applying PXI288 to the groove region of the can prior to the brazing process. (See figure I, C and $D_{\text {; }}$ figure II.)

TECHNIQUES AND OBSERVATIONS

Pilot Plant Testing

With the decision to use an experimental product to reduce AlSi slopovers, 306 pilot scale testing was initlated. Earlier tests using Diversey PXI275 and PXI288 indicated that resultant non-wetting of gluminum components treated with these compounds could be used to advantage. PWR 122-61 (1962) demonstrated that a variety of cans could be masked against molten AlS1 solutions. The subject cans were coated with PXI288 and dipped in the canning furnace without sleeves. In every case the areas of the components treated rendered a clean unbrazed surface as compared to completely brazed areas adjacent to the treated portions. (See figure II. Note the upset metal region of the can.)

Some questions were offered regarding the effect of PXI288 on the closure weld integrity. Inasmuch as the coating could cover the portion of the can normally welded (cap end), and the effects of the PXI288 on brazing were so definite, it remained to be demonstrated that weld quality would not be lessened.

As a demonstration, a large number of $05 \mathrm{~N}$ fuel elements were faced, dipped in PXI288, and welded. In all cases the weld quality was at least as good as normally processed pleces.

It was also determined during this test period that stains caused by the PXI288 during canning were of no concern with regard to hindering formation of an effective autoclave film. Final etch removed the majority of deposits; the residual stains were not discernible after autoclaving.

Only after the aforementloned data had been collected and evaluated, were plans for a 313 feasibility test started.

\section{Bullding Feasibility Testing}

On December 7, 1962, PWR 125 was run on Iine 1 and 2 in 313. The se lines were canning $03 E$ elements, a slop-prone model, and witnessing the usual high CPR rate. It was decided to treat cans and feed them to Iine 1 and 2 in periods. Periods of untreated cans would be run alternately as a control.

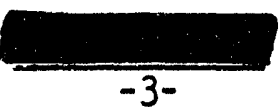


The results were:*

\section{Line 1}

First period (untreated) Second period (treated) Third period (untreated)

$4.4 \% \cdot C P R$

$0.3 \%$ CPR Fourth period (treated)

4.1\% CPR

$0.0 \% \mathrm{CPR}$

\section{Iine 2}

First period (untreated)

second period (treated)

8.4\% CPR

$1.3 \% \mathrm{CPR}$

With confidence in the process innovation building, a similar test was run on December 11:

\section{Iine 1}

Before coating After coating

Ine 2

Before coating After coating

\section{$5.6 \% \mathrm{CPR}$ \\ $0.6 \% \mathrm{CPR}$}

$6.9 \% \mathrm{CPR}$

$0.5 \% \mathrm{CPR}$

By December 13, total production was covered by PWR 125 with a very low CPR rate. It was determined that 70-80\% of the reduced CPR rate was stuck sleeves indicating that slopovers were occurring at an insigaificant rate.

Dn December 20, uncoated cans were used for four hours on swing ishift $(4-8$ p.m. $):$

\begin{tabular}{llccc}
$4: 00-8: 00$ & Line 1 & Iine 6 & Line 3 & Line 5 \\
$8: 30-12: 00$ & $0.8 \%$ & $6.4 \%$ & $2.3 \%$ & $8.0 \%$ \\
\hline & $0.0 \%$ & $1.5 \%$ & $1.7 \%$ & $0.0 \%$
\end{tabular}

The reduced CPR rates in the $8: 30-12: 00$ p.m. period when almost all cans were coated is an indication of the effectiveness of the coating. Since that time, all cans are treated with PXI288. Recent data shows that the CPR rate, including stuck eleeves, spire leakers, slopovers, etc., has stabilized at approximately $0.5 \%$.

During initial 313 testing, a close watch was kept on rejects downstream from canning. There was no indication that the coated cans caused problems anywhere in the process except at component preparation where 


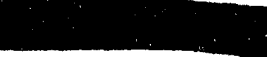

coating of the cans was slow and crude. The paint brush method of application was abandoned in preference to a device developed by Equipment Development. (See figures III and IV.)

Another use was discovered for PXI288 when canning Iine operators found that by dipping their canning tongs in the solution, the molten Alsi did not adhere to them. Prior to this method of coating the tools, a special coating had to be baked on in an oven.

PXI288 has proven very useful in the past year and represents a savings of approximately $\$ 45,000$. In addition, it was cause for submitting of a "Report of Invention" and a subsequent patent award.*

\section{DECLLSSFFED}

* Letter W. E. Johnson to J. D. Schaffer, November 12, 1963. 


\section{$\underline{002 Y}$}

FT. -82046

Co: SMEC. LAB.

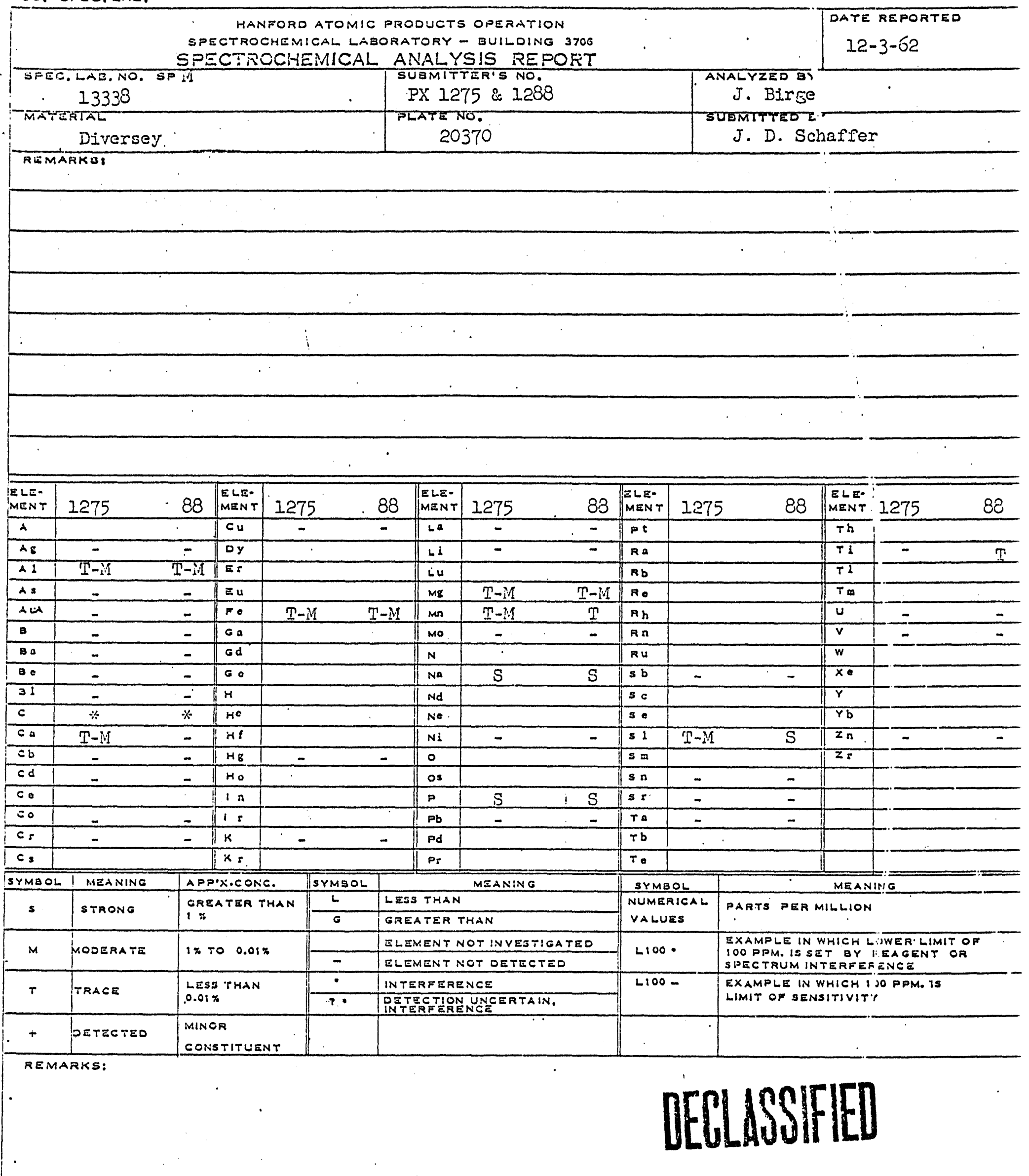

REPORT APPROVED - /s/ P.R. Andelison

$4-\$ 361-\$ 38(9-5 i)$ 
FIGURE I

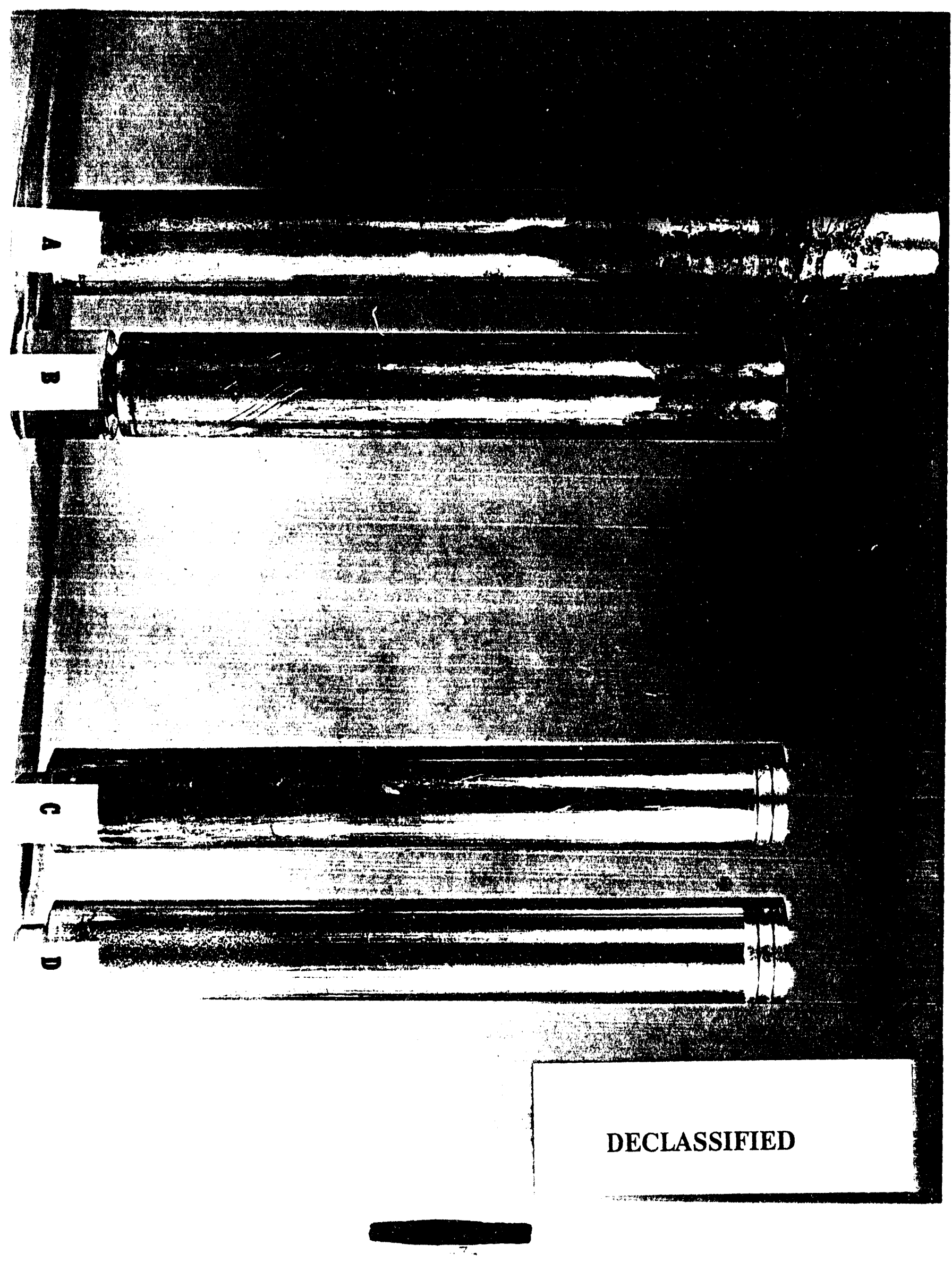


FIGURE II

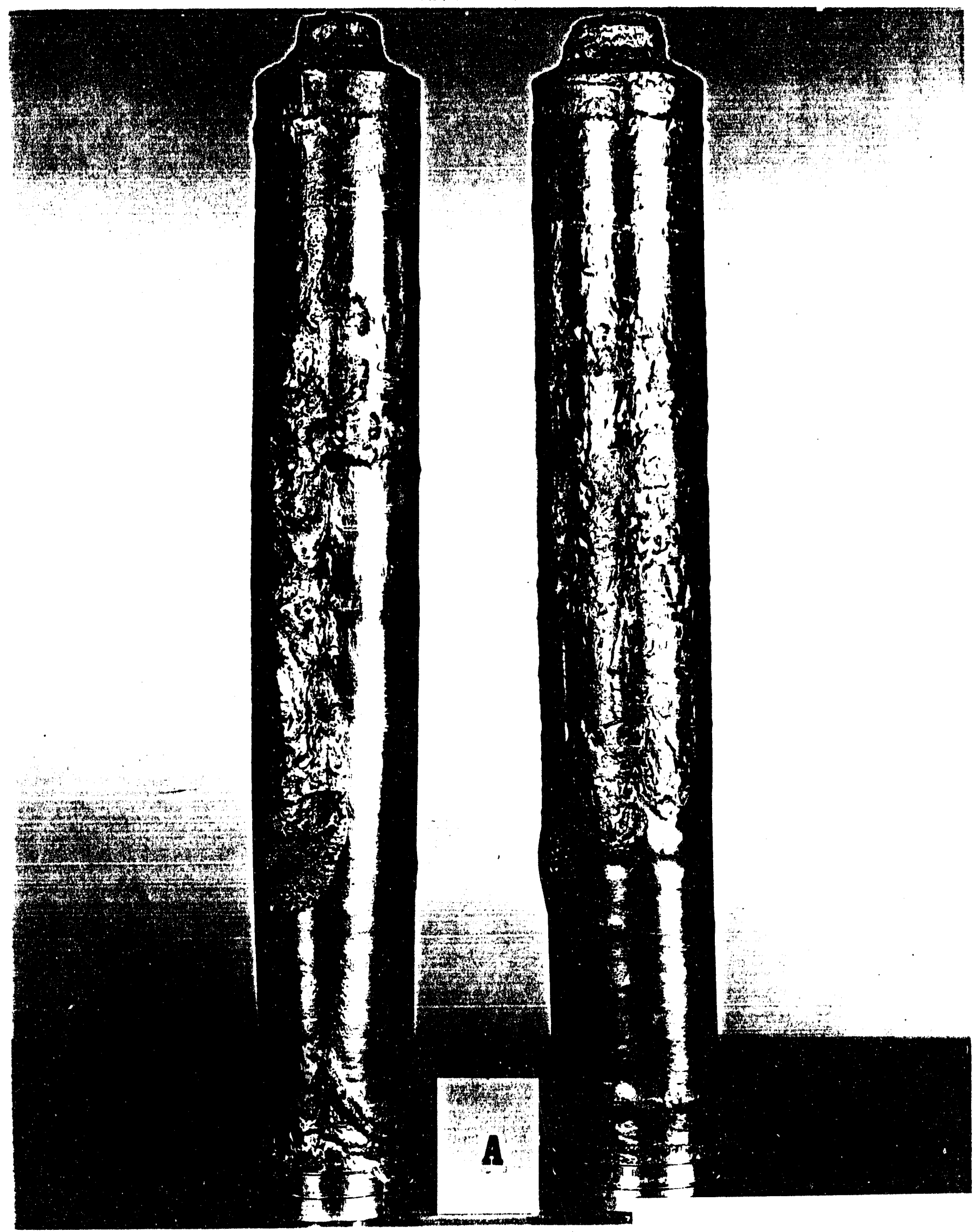

DECLASSIFIED

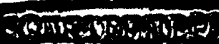




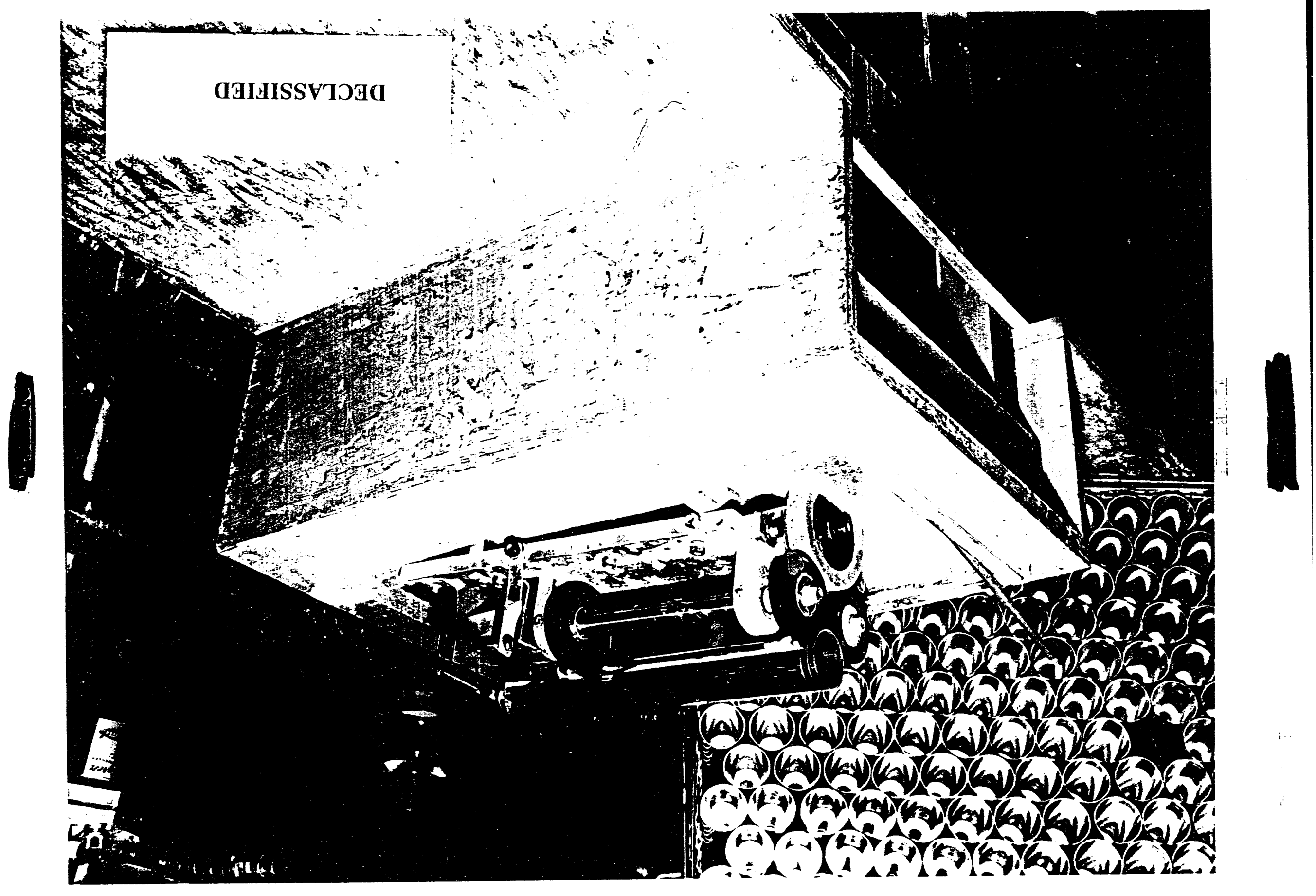




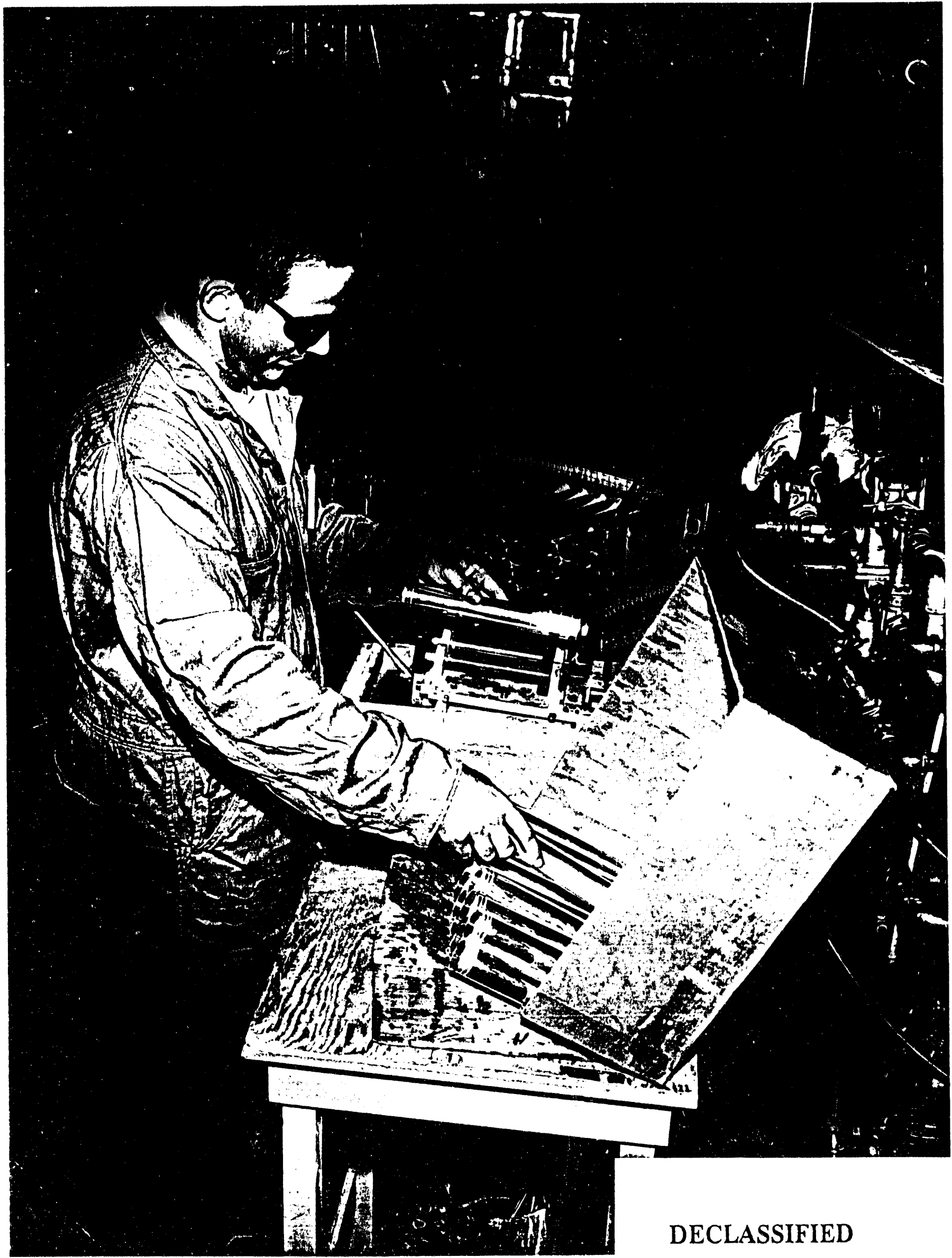



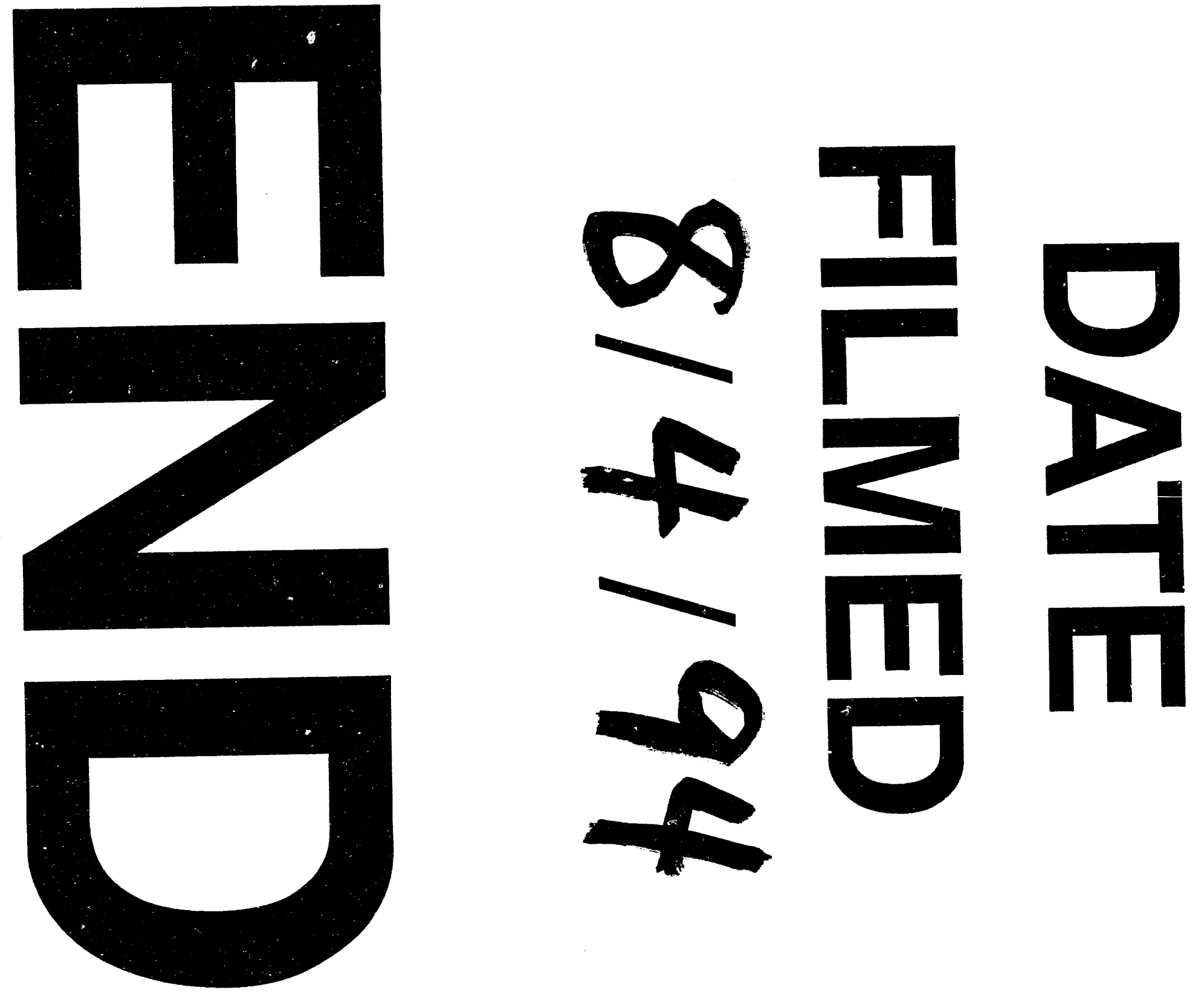
